\title{
Influence of growth regulating chemicals on growth and flowering in Jasmine
} (Jasminum sambac.Ait.)

\author{
D. Dhanasekaran \\ Department of Horticulture, Faculty of Agriculture \\ Annamalai University, Annamalai Nagar - 608002 \\ Tamil Nadu, India \\ E-mail:dhansflora@gmail.com
}

\begin{abstract}
Jasmine is an important commercial flower crop in Tamil Nadu. The crop has a main flowering season during March to October and an off-season from November to February. During this off-season, flowering is very poor or there is no flowering in many growing areas. In recent years, growth regulators are valuable in floriculture for manipulating growth and flowering of many crops and hence and attempt has been made to induce flowering during off season using growth regulators in Jasmine in the Floriculture unit of the Department of Horticulture, Faculty of Agriculture, Annamalai University, Tamil Nadu during November, 2016 to February, 2017. The treatment comprises of three concentrations of each of two growth promoting substances viz., NAA and $\mathrm{GA}_{3}$ and two growth retardants (Cycocel and Maleic Hydrazide). The experiment was laid out in randomized block design with three replications. Among the various treatments, application of NAA @ 75 ppm $\left(T_{6}\right)$ recorded the highest plant height $(130.6 \mathrm{~cm}$ and $178.5 \mathrm{~cm}$ at 90 and 180 DAP respectively), number of primary shoots (21.68 and 35.68 at 90 and 180 DAP respectively), number of nodes $(9.86$ and $15.89 \mathrm{~cm}$ at 90 and $180 \mathrm{DAP}$ respectively $)$ and number of leaves (1250.0 and 2689.5 at 90 and 180 DAP respectively). Earliness in flowering (26.38 DAP) and maximum duration of flowering (171.00 days) was noticed in $\left(\mathrm{GA}_{3} @ 150 \mathrm{ppm} \mathrm{T}_{3}\right)$. From the above studies, it is inferred that application of $\mathrm{GA}_{3} @ 150 \mathrm{ppm}$ could be recommended for enhanced growth and higher flower yield in Jasminum sambac.
\end{abstract}

Keywords : Jasmine, growth regulators, NAA,GA,CCC, MH,off-season flowering

\section{INTRODUCTION}

Jasmine is one of the oldest fragrant flowers. A serious limiting factor is that the flowering of Jasminum sambac is seasonal. There are peak and lean productive seasons with consequent gluts and scarcity which affect the price trends greatly. Regulation of plant growth and development using natural plant hormones for greater production has received the utmost attention (Leetham et al., 1978). Growth and flowering responses of flower crops to these chemical substances have been intensively studied with a view to have compact plants with greater number of flowers and also to hasten or delay flowering according to the needs of the grower (Cathey, 1980).

Regulation of flowering in jasmine has immense practical value. Timing of the peak flowering to coincide with the time of greatest demand and generally modifying the flowering sequence to avoid peak production at about the same time would confer great advantage to the grower and consumers. It is in this respect that the possibility of using plant growth regulators for regulation assumes significance. Keeping this in view, the present investigation was therefore taken to study the effect of growth regulators and their concentration on growth and flowering of Jasmine (Jasminum sambac Ait.).

An experiment was formulated with two growth promoters $\left(\mathrm{GA}_{3}\right.$ and NAA) and two growth retardants (CCC, $\mathrm{MH})$ at three concentrations each were taken up in the floriculture unit during November, 2016 to February, 2017. Thirteen treatments comprising GA3 at 50, 100 and $150 \mathrm{ppm}, \mathrm{NAA}$ at 25, 50, $75 \mathrm{ppm}$, Cycocel at 500, 1000 and $1500 \mathrm{ppm}$ and Maleic hydrazide at 1000, 2000 and $3000 \mathrm{ppm}$ concentration and a control was replicated thrice. Three year old 
jasmine plants were selected from the floriculture unit of the Department of Horticulture, Faculty of Agriculture, Annamalai University, Tamil Nadu for the experiment. Four plants were maintained for each treatment per replication along with a control and conventional pruning during second fortnight of October, 2016. After pruning, when the new shoots appeared with sufficient number of leaves, the freshly prepared Gibberellic acid $\left(\mathrm{GA}_{3}\right)$, Naphthalene acetic acid (NAA), 2-chloroethyl-trimethyl ammonium chloride; Chlorocholine chloride (Cycocel CCC) and Maleic hydrazide $(\mathrm{MH})$ were sprayed once as per the treatments. The data on vegetative parameters viz., plant height, number of primary shoots, number of nodes, intermodal length, number of leaves and flowering parameters viz., days taken for flowering, duration of flowering, flower yield and hundred flower weight were recorded. The statistical analysis of the data was done by adopting the standard procedure given by Panse and Sukhatme (1967).

The results of the investigation undertaken with a view to study the effect of certain plant growth regulators on flowering and yield of Jasmine (Jasminum sambac Ait.) are presented in Table1 and 2. Among the various treatments, application of NAA @ 75 ppm $\left(\mathrm{T}_{6}\right)$ recorded the highest plant height $(130.6 \mathrm{~cm}$ and $178.5 \mathrm{~cm}$ at 90 and 180 DAP, respectively) and it was followed by $\left(\mathrm{T}_{3}\right)$ Gibberllic acid @ $150 \mathrm{ppm}$ which recorded the value of $127.8 \mathrm{~cm}$ and $175.5 \mathrm{~cm}$ at 90 and 180 DAP, respectively. The PGR'S when applied as foliar spray, were absorbed by the leaves and readily translocated in both xylem and phloem tissues resulting in distribution throughout the plant system. This might be the reason for the enhancement in plant height. The least plant height $(98.9 \mathrm{~cm}$ and $142.1 \mathrm{~cm}$ at 90 and 180 DAP respectively was observed in $\mathrm{T}_{8}$ (Cycocel @ 1000 ppm). Cycocel has dwarfening effect on the plant (Dole and Wilkins, 1999). This causes the internodes to shorten and stems to harden due to thickness.

Among the various treatments the maximum number of primary shoots was registered in NAA @ $75 \mathrm{ppm}\left(\mathrm{T}_{6}\right)$ which recorded the highest values $(21.68$ and 35.68 at 90 and 180 DAP, respectively). This was followed by the treatment NAA @ 50 ppm $\left(\mathrm{T}_{5}\right)$ which recorded the value of 19.88 and 33.18 at 90 and 180 DAP, respectively.
Significant differences were observed among the growth regulators tried in Jasmine. Foliar spray of Gibberellic acid $\left(\mathrm{GA}_{3} @ 150 \mathrm{ppm}\left(\mathrm{T}_{3}\right)\right.$ resulted in more number of internodes (17.98 and 43.59 at 90 and 180 DAP respectively), which is followed by $\left(\mathrm{T}_{9}\right)$ Cycocel @ 1500 ppm (17.00 and 41.69 at 90 and 180 DAP respectively). However least number of nodes was registered in $\mathrm{T}_{13}$ (Control) with a value of 8.27 and 23.09 at 90 and 180 DAP respectively.

The data presented in Table 1 clearly shows that the length of internodes was significantly increased by the application of NAA @ 75 ppm $\left(\mathrm{T}_{6}\right)$ (9.86 and $15.89 \mathrm{~cm}$ at 90 and 180 DAP respectively). This was followed by $\left(\mathrm{T}_{3}\right)$ Gibberellic acid @150 ppm (8.96 and 14.59 at 90 and 180 DAP respectively). The maximum number of leaves per plant was recorded in the treatment $\mathrm{T}_{3}-\mathrm{GA}_{3} @ 150$ ppm (1250.0 and 2689.5 at 90 and 180 DAP, respectively). This might be attributed to the enhanced vegetative growth in early phase due to exogenous application of $\mathrm{GA}_{3}$ which would have favoured the increased photosynthesis and $\mathrm{Co}_{2}$ fixation. The least number of leaves was registered in $\mathrm{T}_{13}$ (Control) a value of 794.4 and 2070.2 at 90 and 180 DAP respectively. The increased effect could be corroborated with the findings of Sridhar et al (2013) and Pappaiah and Muthusamy (1978) in Jasminum auriculatum.

The increased effect of NAA@75 ppm for the above characters might be due to the fact that NAA would have promoted vegetative growth by inducing active cell division in the apical meristem. Increase in growth attributes due to the application of the NAA in the present study is in consonance with the findings of Sridhar et al (2013). Similar results were also derived by Pal et al., (1980) in Jasmine and Grisha et al (2012) in Daisy.

Earliness in flowering (26.38 DAP) was noticed in plants sprayed with $\mathrm{GA}_{3} @ 150$ ppm $\left(\mathrm{T}_{3}\right)$ followed by $\mathrm{GA}_{3} @ 100$ ppm $\left(\mathrm{T}_{2}\right)$ with took 30.38 days. This might be attributed to the enhanced vegetative growth in early phase attributed by exogenous application of $\mathrm{GA}_{3}$ which would have favoured the increased photo synthesis and $\mathrm{CO}_{2}$ fixation. Further, it would have favoured convenience of factors influencing floral initiation ie., carbohydrate pathway and photo periodic pathway with $\mathrm{GA}_{3}$ pathway. These results are in accordance with findings of Baskaran et al.,(2007) and Devadanam et al., (2007) in Gladiolus. Delayed 


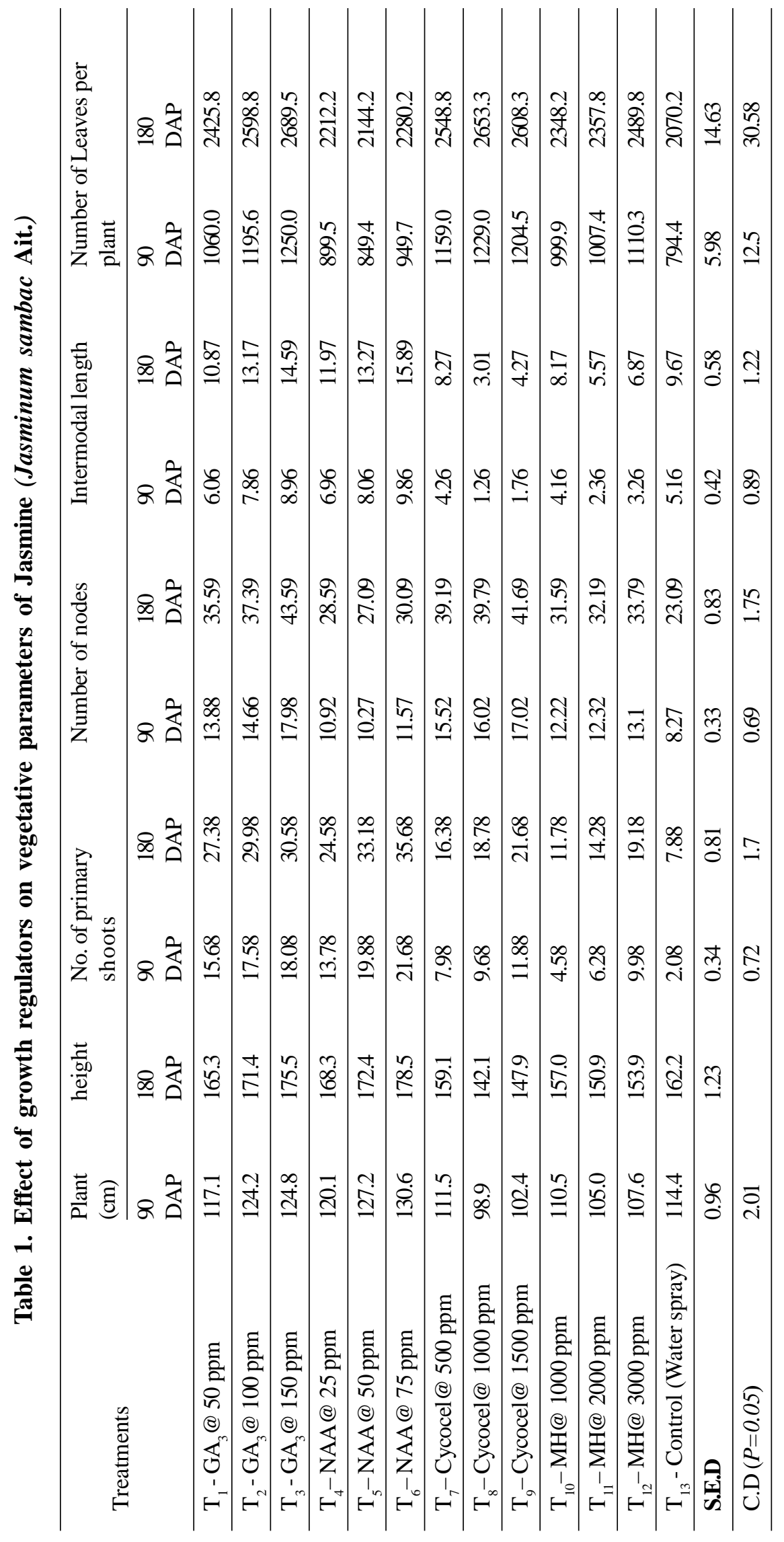




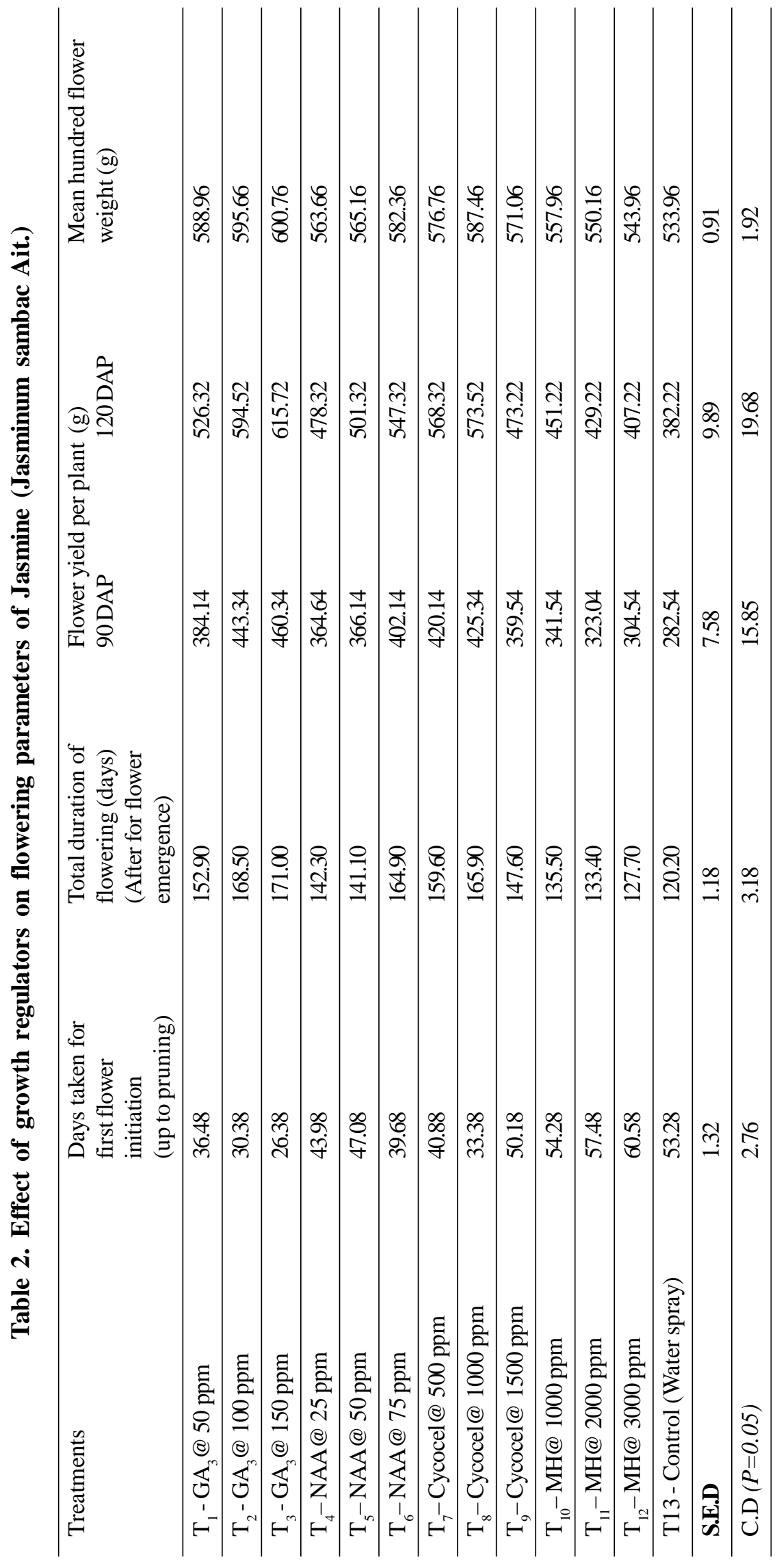


flowering was recorded in $\mathrm{T}_{12} \mathrm{MH} @ 3000$ ppm(60.58 days). This might be due to lesser mitotic activity and preservation of bio-synthesis of gibberellic acid like substances. These results are in agreement with the findings of Sen and Maharana (1971) and Dutta et al., (1993) in Chrysanthemum. Dalal et al., (2009) stated that the delayed flowering might be due to influence of growth retardants in reducing the partition of carbohydrates to floral organ when compared to control.

Maximum flowering duration was in $\mathrm{GA}_{3} @ 150$ ppm $\left(\mathrm{T}_{3}\right)$, which recorded 171.00 days, followed by GA $@ 100$ ppm $\left(\mathrm{T}_{2}\right)$ with168.5 days. This might be attributed to the enhanced vegetative growth in early phase attributed by exogenous application of $\mathrm{GA}_{3}$ would have favoured carbohydrate pathway. The longevity of flowering was also observed by Sridhar et al., (2013) in Jasminum auriculatum and Dalal et al., (2009) in chrysanthemum.

The minimum duration of flowering was recorded in control $\left(\mathrm{T}_{13}\right)$ with120.20 days. Among the various treatments significant increase in flower yield per plant was recorded in $\mathrm{GA}_{3} @ 150 \mathrm{ppm}\left(\mathrm{T}_{3}\right)$ with a value of 460.34 and 615.72 g plant $^{-1}$ at 90 and 120 DAP respectively. This is followed by $\mathrm{GA}_{3}$ @ $100 \mathrm{ppm}\left(\mathrm{T}_{2}\right) 443.34$ and $594.52 \mathrm{~g} \mathrm{plant}^{-1}$ at 90 and 120 DAP respectively. The increase in weight of flowers might be due to the production of more number of secondary shoots at early stage, which then had sufficient time to accumulate reserve carbohydrates for proper flower bud differentiation. The lowest yield was observed in $\mathrm{T}_{13}$-Control (282.54 and $382.22 \mathrm{~g}$ plant $^{-1}$ ) at 90 and 180 DAP respectively. Among the treatments, $\mathrm{GA}_{3} @ 150 \mathrm{ppm}\left(\mathrm{T}_{3}\right)$ recorded the highest value of $600.76 \mathrm{~g}$ followed by $\mathrm{GA}_{3} @ 100 \mathrm{ppm}\left(\mathrm{T}_{2}\right)$ $(595.66 \mathrm{~g})$. The lowest hundred bud weight was recorded in $\mathrm{T}_{13}$ - Control (533.96 g). This might be attributed to the enhanced vegetative growth in early phase attributed by exogenous application of $\mathrm{GA}_{3}$ which would have favoured the increased photosynthesis and $\mathrm{CO}_{2}$ fixation. In the present study, the data on extended duration of flowering and hundred bud weight due to the application of $\mathrm{GA}_{3} @$ $150 \mathrm{ppm}$ might also be a cause for increase in yield.

Earlier reports indicated that the growth and yield of Jasminum grandiflorum was enhanced by application of $\mathrm{GA}_{3}$ (Bhattarcharjee, 1983), Narayana Gowda (1985) and Sridhar et al., (2013).Similar findings were also recorded by Amit kumar et al., (2011) in African marigold, Shinde et al., (2010) in chrysanthemum.

From the above studies, it is inferred that application of $\mathrm{GA}_{3} @ 150$ ppm could be recommended for enhanced growth and higher flower yield in Jasminum sambac.

\section{REFERENCES}

Amit Kumar, Kumar,J., Mohan,B., Singh,J.P., Rajbeer and Ram,N. 2011. Effect of plant growth regulators on growth, flowering and yield of African marigold (Tagetes erecta L.) cv. Pusa Narangi Gainda. Asian J. Hort., 6(2): 418-422.

Baskaran, V., Misra,R.L. and Abirami,K. 2007. Effect of plant growth regulators of corm production in gladiolus. J. Ornamental Hort. Sci., 4(1): 7880 .

Bhattacharjee, S. K., 1983, Growth and flowering of Jasminum grandiflorum L. as influenced by growth regulating chemicals. Singapore J. PrimaryIndustries, 11(1): 34-38.

Cathey, M. H., 1980, Phosphon and CCC for controlling height of chrysanthemum. Floriculture Ex., 135: 12-13.
Devadanam, A., Shinde,B.N., Sable, P.B. and Vedpathak,S.G. 2007. Effect of foliar spray of plant growth regulators on flowering and vase life of Tuberose (Polyanthus tuberose L.). J. Soil and Crops, 17(1): 86-88.

Dole, J.M. and H.F. Wilkins 1999. Floriculture Principles and Species; Prentice - Hall. Inc, U.S.A, 555-558.

Dutta, J.P., Seemandhini, R. and Khader,M.A. 1993. Regulation of flowering in chrysanthemum (Chrysanthemum indicum L.)Cv.CO-1 by use of growth regulators. South Indian Hort., 41(5):293-299

Dalal. S.R, Karale, GD. and Momin, C.K. 2009. Effect of growth regulators on growth, yield and quality of Chrysanthemum under net house conditions. Asian.J.Hort., 4(1):161-163. 
Grisha, R.,Shirol,A.M., Kulkarni, B.S., Reddy,B.S. and Anupa,T. 2012. Studies on effect of different plant growth regulators on growth, flowering and quality of Daisy (Aster amellus L.) cv. Dwarf Pink. Int. J. Agric. Env. Biotech. 5(2): 127-131.

Leetham, D. S., Goodwing,P.B. and Higgins, T.J.V. 1978. Phytohormones and related components, A comprehensive treatise Vol. 2, Elsevier, Amsterdam.

Narayana Gowda, J. V., 1985. Effect of gibberellic acid on growth and flowering of rose cv. Superstar. The Indian Rose Annual, IV: 185188.

Panse, V.G. and Sukhatme,P.V.(1967). Statistical methods for Agricultural workers, ICAR, New Delhi.

Pal, P., Maity, R. G. and Bose, T. K.1980. Effect of growth regulators on Jasminum sambac var. Double. National Seminar on Production Technology for Commercial Flower Crops, 20 and 30 August, Tamil Nadu Agricultural University, Coimbatore, pp. 35-38.
Pappaiah, C. M. and Muthuswamy, S., 1978. Effect of growth regulators on growth, flowering and quality and essential oil content of Jasminum auriculatum var. Parimullai. South Indian Horti., 26: 66-71

Sen, S.K. and Maharana, T. 1971. Growth and flowering response of Chrysanthemum to growth regulator treatments. Punjab Hort. J., 11:276-279.

Shinde, K.H. , Praekh,N.S., Upadhay,N.V. and Patel, H.C. 2010. Investigation of different levels of gibberellic acid $\left(\mathrm{GA}_{3}\right)$ and pinching treatments on growth, flowering and yield of chrysanthemum (Chrysanthemum morifolium Ramat.) cv. IIHR-6 under middle Gujarat conditions. Asian J. Hort., 5(2): 416-419.

Sridhar, P., Angadi,S.G., Kiranmai,S. and Anil Kumar. 2013. Effect of growth promoters and growth retardants on different growth parameters in jasmine (Jasminum auriculatum vahl.). Plant Archives., 13(1): 569-571.

(MS Received 25 November 2017, Revised 26 July 2018, Accepted 13 December 2018) 